\title{
HILLSLOPE RUNOFF GENERATION - COMPARING DIFFERENT MODELING APPROACHES
}

\author{
HELENA PAVELKOVÁ, MICHAL DOHNAL, TOMÁŠ VOGEL*) \\ Czech Technical University in Prague, Faculty of Civil Engineering, Thákurova 7, 16629 Prague 6, Czech Republic; \\ ${ }^{*}$ Corresponding author, Tel.: +420 22435 4341; fax: +420 224354 793; Mailto: vogel@fsv.cvut.cz
}

This study focuses on modeling hydrological responses of shallow hillslope soil in a headwater catchment. The research is conducted using data from the experimental site Uhliřská in Jizera Mountains, Czech Republic. To compare different approaches of runoff generation modeling, three models were used: (1) onedimensional variably saturated flow model S1D, based on the dual-continuum formulation of Richards' equation; (2) zero-dimensional nonlinear morphological element model GEOTRANSF; and (3) semidistributed model utilizing the topographic index similarity assumption - TOPMODEL. Hillslope runoff hydrographs and soil water storage variations predicted by the simplified catchment scale models (GEOTRANSF and TOPMODEL) were compared with the respective responses generated by the more physically based local scale model S1D. Both models, GEOTRANSF and TOPMODEL, were found to predict general trends of hydrographs quite satisfactorily; however their ability to correctly predict soil water storages and inter-compartment fluxes was limited.

KEY WORDS: Rainfall-Runoff Modeling, Hillslope Discharge, Soil Water Storage, Transmisivity, Topographic Index, Richards' Equation, Preferential Flow.

Helena Pavelková, Michal Dohnal, Tomáš Vogel: TVORBA ODTOKU ZE SVAHU - POROVNÁNÍ ROZDÍLNÝCH MODELOVÝCH PŘÍSTUPU゚. J. Hydrol. Hydromech., 60, 2012, 2; 29 lit., 8 obr., 2 tab.

Studie je zaměřena na modelování hydrologické reakce mělké svahové půdy v pramenné části povodí Nisy, k výzkumu byla použita data z experimentálního povodí Uhlířská. Porovnání různých konceptuálních představ modelování odtoku bylo uskutečněno pro: (1) jednorozměrný model proměnlivě nasyceného proudění S1D; (2) model založený na bezrozměrném nelineárním morfologickém prvku - GEOTRANSF a (3) semi-distribuovaný model využívající principu podobnosti na základě topografického indexu - TOPMODEL. Hydrogramy odtoku ze svahu a změny zásob vody v půdě vypočtené zjednodušenými modely GEOTRANSF a TOPMODEL byly porovnány s odpovídajícími odezvami fyzikálně založeného modelu S1D. Oba modely, GEOTRANSF i TOPMODEL, byly poměrně úspěšné v předpovědi základních trendů hydrogramů odtoku, jejich schopnost správně předpovídat zásoby vody v půdě a toky mezi nimi však byla omezená.

KLÍČOVÁ SLOVA: srážko-odtokové modelování, odtok ze svahu, zásoba vody v půdě, transmisivita, topografický index, Richardsova rovnice, preferenční proudění.

\section{Introduction}

In the last few decades, processes related to runoff formation in headwater catchments, especially during extreme hydrological events, have received growing attention. A fast reaction of discharge to rainstorms is typical for small mountainous catchments. Shallow subsurface runoff is considered to be a significant component of the rainfall-runoff relationship in such catchments. It is generally assumed that this type of runoff (further on referred to as hypodermic flow) takes place after a saturated zone has formed above an impermeable or less permeable subsurface layer (hard bedrock or a less permeable soil layer). Soil water then flows laterally in the direction determined by the local slope of the soil-bedrock interface.

Of the currently available models used to describe actual processes taking place at the hillslope scale, probably the most detailed one is the model based on three-dimensional Richards' equation. Such a model and other similar physically based 
models are strongly non-linear and require iterative numerical solution. A vast number of linearized equations have to be solved when this type of model is applied to a hydrological problem, even if modest spatial dimensions are considered (such as dimensions of a single hillslope). To estimate parameters for these models, detailed knowledge of soil hydraulic characteristics is necessary. This information is commonly unavailable, especially at the entire catchment scale (Lichner et al., 2011). In order to obtain hydrological predictions at this scale, it is necessary to use simplified conceptual models.

Over the years, many conceptual approaches to subsurface runoff modeling were discussed and compared in the literature. The kinematic wave equation (e.g. Fan and Bras, 1998; Troch et al., 2002) and the Boussinesq equation (e.g. Troch et al., 2003; Hilberts et al., 2004) were applied to model hypodermic flow. Richards' equation was used to describe hillslope soil water movement under variably saturated conditions e.g. by Paniconi et al. (2003), Hilberts et al. (2007) and Cordano and Rigon (2008). A combination of Richards' equation and diffusion wave equation was used by Vogel at al. $(2005 \mathrm{a}, 2005 \mathrm{~b})$ to model hypodermic flow in the Uhliřská catchment.

TOPMODEL (e.g. Beven, 2001) has been widely discussed and tested (Ambroise et al., 1996; Blažková and Beven, 1997). Applications of TOPMODEL in the Uhlírská catchment have been reported by Blažková and Beven (1997) and Blažková et al. (2002a and 2002b).

Recently, Majone et al. (2010) presented a simpler model (further on referred to as GEOTRANSF) developed for modeling subsurface runoff genera- tion using non-linear relationship between runoff and soil water storage.

In this paper, three models were used to simulate runoff from a hillslope: (1) one-dimensional variably saturated flow model S1D, based on dualcontinuum formulation of the Richards equation; (2) zero-dimensional non-linear morphological element model GEOTRANSF; and (3) model utilizing the topographic index similarity assumption TOPMODEL. The main objective of this comparative study was to analyze the performance of the two simplified models (GEOTRANSF and TOPMODEL) by comparing them with the more physically based model (S1D), and to assess the ability of the models to predict soil water storages and internal fluxes in addition to discharge hydrographs.

\section{Material and methods S1D model}

This physically based local scale model was designed to simulate flow of water in soils with preferential pathways. It is based on the dualcontinuum approach. The approach assumes that soil water moves in two separate flow domains, one representing the soil matrix and the other representing the network of preferential pathways (denoted as SM domain and PF domain). Under saturated or nearly saturated conditions, soil water contained in the preferential flow domain flows considerably faster than that in the soil matrix domain. Soil water flow is in each of the two domains described by Richards' equation (in a similar way as in Gerke and van Genuchten, 1993). The resulting set of the two coupled governing equations can be written as:

$$
\begin{aligned}
& w_{f} C_{f} \frac{\partial h_{f}}{\partial t}=\frac{\partial}{\partial z}\left[w_{f} K_{f}\left(\frac{\partial h_{f}}{\partial z}+1\right)\right]-w_{f} S_{f}-\alpha_{w}\left(h_{f}-h_{m}\right) \\
& w_{m} C_{m} \frac{\partial h_{m}}{\partial t}=\frac{\partial}{\partial z}\left[w_{m} K_{m}\left(\frac{\partial h_{m}}{\partial z}+1\right)\right]-w_{m} S_{m}+\alpha_{w}\left(h_{f}-h_{m}\right)
\end{aligned}
$$

where $f$ refers to PF-domain and $m$ to SM-domain, $w_{m}$ and $w_{f}-$ volume fractions of the respective domains $\left(w_{m}+w_{f}=1\right), C$ - the differential soil water capacity $\left[\mathrm{m}^{-1}\right], h-$ the pressure head $[\mathrm{m}], K-$ the unsaturated hydraulic conductivity $\left[\mathrm{m} \mathrm{s}^{-1}\right], S-$ the local intensity of root extraction $\left[\mathrm{s}^{-1}\right]$ and $\alpha_{w}-$ the transfer coefficient controlling the dynamic exchange of water between the two flow domains $\left[\mathrm{s}^{-1} \mathrm{~m}^{-1}\right]$. The governing equations are coupled through a first order transfer term $\Gamma_{w}\left[\mathrm{~s}^{-1}\right]$ defined according to Gerke and van Genuchten (1993) as $\Gamma_{w}=\alpha_{w}\left(h_{f}-h_{m}\right)$. 
Vertical fluxes predicted at the lower boundary of the dual-continuum system (by S1D model) determine the recharge rate for the hypodermic flow. In general, the vertical recharge rate $R\left[\mathrm{~m} \mathrm{~s}^{-1}\right]$ can be calculated from a simple continuity equation formulated at the soil-bedrock interface:

$$
R=w_{f}\left(q_{f 1}-q_{f 2}\right)+w_{m}\left(q_{m 1}-q_{m 2}\right)
$$

where the first term represents the recharge contributions from the PF domain and the second one from the SM domain, respectively, $q_{1}$ and $q_{2}$ are soil water fluxes $\left[\mathrm{m} \mathrm{s}^{-1}\right]$ above and below the soil/bedrock interface (Fig. 1). The $q_{2}$ fluxes represent seepage to deeper horizons. In the present application of the model, we assume that $q_{m 2}=q_{m 1}$ and $q_{f 2}=0$, i.e. the deep percolation is associated with the SM-domain flux while the PF-domain flux contributes to hypodermic flow. This leads to $R=$ $=w_{f} q_{f 1}$.

S1D can handle hysteresis of soil hydraulic properties. However, this option was not used in the present study, i.e. hysteresis was assumed to be insignificant. This was partly supported by the results of our previous study (Dohnal et al., 2006).

In addition, we assume that the modeled hillslope segment at Uhlírska (being short, shallow and well permeable) does not cause any substantial runoff transformation in lateral direction and the hillslope discharge can be computed from a simple quasisteady-state formula:

$$
Q(t)=A R(t)
$$

where $A$ is the hillslope contributing area $\left[\mathrm{m}^{2}\right]$.

The local saturated zone storage $S_{S Z}[\mathrm{~m}]$, representing the amount of water which takes part in hypodermic flow, is determined by the depth of hypodermic stream $h_{S Z}[\mathrm{~m}]$ and the effective porosity $\Theta[-]$, i.e.:

$$
S_{S Z}(t)=\Theta h_{S Z}(t)
$$

If $Q$ is calculated from (4), we can estimate $h_{S Z}$ from the kinematic wave approximation of Darcy's law (i.e., vertically integrated Darcy equation stripped of the pressure gradient):

$$
\frac{Q(t)}{B}=K_{e f f} h_{S Z}(t) \frac{\partial z}{\partial x}
$$

where $K_{\text {eff }}$ is the effective saturated hydraulic conductivity $\left[\mathrm{m} \mathrm{s}^{-1}\right], B$ - the local width of the hillslope $[\mathrm{m}]$ and $\partial z / \partial x$ is equal to the cosine of the local hillslope angle.
The dual set of governing equations for soil water flow is solved numerically by the S1D code. The most recent implementation of S1D is described in Vogel et al. (2010a)

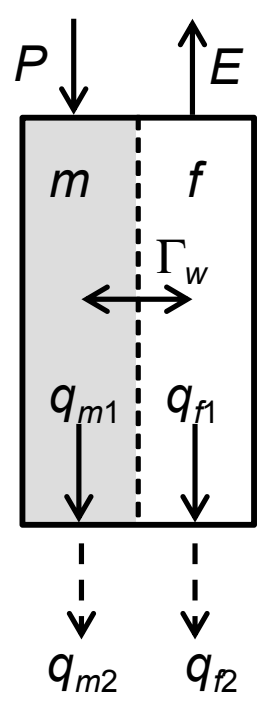

Fig. 1. Schematic of S1D domains and fluxes. The soil is decomposed into two flow domains: the soil matrix domain $(\mathrm{m})$ and preferential flow domain $(f) . q_{m 1}$ and $q_{f 1}$ are the lower boundary soil water fluxes, $q_{m 2}$ and $q_{f 2}$ are the fluxes representing leakage to deeper horizons, and $\Gamma_{w}$ is the inter-domain soil water transfer.

\section{GEOTRANSF model}

A simple conceptual model of subsurface runoff generation was suggested by Majone et al. (2005, 2010). In this paper, we refer to this model as GEOTRANSF - according to Majone et al. (2005). In GEOTRANSF, locally generated vertical flux at the base of the soil profile is estimated from:

$$
q_{h}(t)= \begin{cases}q_{0} \exp \frac{S(t)-S_{0}}{m} & \text { for } \quad S \geq S_{0} \\ q_{0} & \text { for } \quad S<S_{0}\end{cases}
$$

where $m$ is an empirical parameter [m], $S$ - the soil water storage $[\mathrm{m}], q_{0}-$ the specific discharge $\left[\mathrm{m} \mathrm{s}^{-1}\right]$, associated with a minimum threshold value of soil water storage $S_{0}$.

The vertical soil water flux is divided into two components (Fig. 2): (i) a fast flow through macropores recharging hypodermic flow:

$q_{s}(t)=\left(1-c_{p}\right) q_{h}(t)$

and (ii) a deep percolation component representing seepage to underlying horizons: 
$q_{d p}(t)=c_{p} q_{h}(t)$

where $c_{p}$ is the partition coefficient [-].

Water storage in the soil profile is calculated from the mass balance equation:

$\frac{\Delta S}{\Delta t}=P-E-q_{h}$

where $P$ is the infiltration intensity $\left[\mathrm{m} \mathrm{s}^{-1}\right]$ due to rainfall and $E$ is the actual evapotranspiration intensity $\left[\mathrm{m} \mathrm{s}^{-1}\right]$.

Majone et al. (2010) used instantaneous unit hydrograph method to transform the recharge signal $q_{s}(t)$ into streamflow hydrograph. In our study, GEOTRANSF is first used to calculate the hypodermic flow recharge $R(t)=q_{s}(t)$. The hillslope discharge hydrograph is then simply estimated by applying the quasi-steady-state assumption (4).

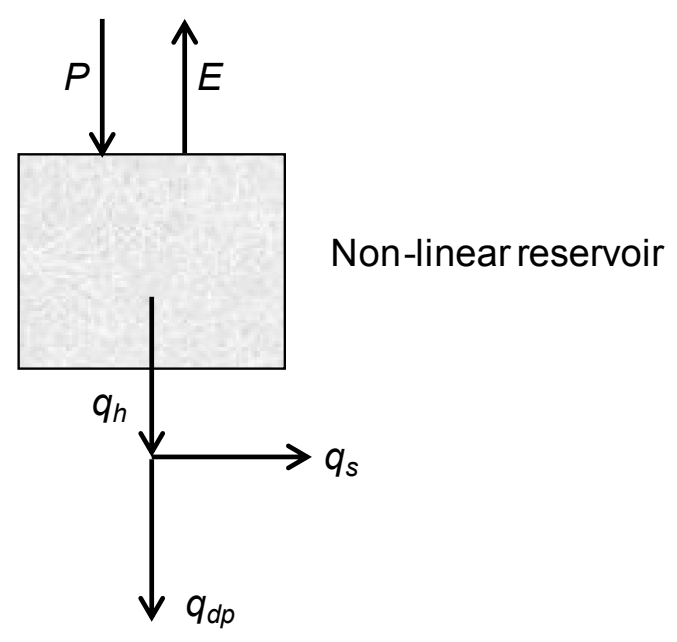

Fig. 2. Schematic of GEOTRANSF fluxes.

\section{TOPMODEL}

TOPMODEL utilizes a concept of topographic index originally developed by Kirkby (1975) and extended to the soil-topographic index by Beven (1986):

$I_{j}=\ln \frac{a_{j}}{T_{0} \tan \beta_{j}}$

where $I$ is the topographic index, $a_{j}$ is the contributing area of the hillslope per unit contour length [m] drained through point $j, T_{0}-$ the lateral transmissivity at full soil saturation $\left[\mathrm{m}^{2} \mathrm{~s}^{-1}\right], \beta$ - the local angle of the hillslope. The locations exhibiting sim- ilar values of $I$ are considered to belong to the same topographic index class.

TOPMODEL (e.g. Beven, 2001) is based on three basic assumptions: (i) quasi-steady-state relationship between the saturated zone recharge and the hillslope discharge, (ii) approximation of the effective hydraulic gradient by the local surface topographic slope and (iii) a simplified relationship between the saturated zone transmissivity and the local storage deficit. The TOPMODEL version used in this study assumes exponential relationship between transmissivity and storage deficit.

According to the quasi-steady-state assumption, the hillslope discharge caused by saturated subsurface runoff can be estimated from:

$q_{j}(t)=a_{j} r(t)$

where $q$ is the subsurface discharge per unit contour length $\left[\mathrm{m}^{2} \mathrm{~s}^{-1}\right]$ and $r$ - the saturated zone recharge rate $\left[\mathrm{m} \mathrm{s}^{-1}\right]$, assumed to be spatially uniform.

If exponential relationship between the transmissivity and storage deficit is assumed, local saturated zone storage deficit $D[\mathrm{~m}]$ can be calculated from the corresponding value of soil-topographic index and the average storage deficit of the catchment:

$$
D_{j}-\bar{D}=-m\left(I_{j}-\bar{I}\right)
$$

where $m[\mathrm{~m}]$ is a parameter controlling the rate of decline of transmissivity with increasing storage deficit and the overbars refer to the catchment scale averages.

The version of TOPMODEL applied in this paper (see Beven, 2001) uses three individually balanced water storages (Fig. 3): (i) spatially uniform variably saturated root zone storage, (ii) spatially distributed gravity-drainable unsaturated zone storage and (iii) catchment scale saturated zone storage represented by the average storage deficit.

The root zone water balance, is calculated according to:

$$
\begin{aligned}
& \frac{\Delta S_{R Z}}{\Delta t}=P-E-\frac{\delta S_{R Z}}{\Delta t} \\
& \delta S_{R Z}=\max \left(S_{R Z}-S_{R Z \max }, 0\right)
\end{aligned}
$$

where $S_{R Z}$ is the instantaneous water storage in the root zone [m], assumed to be uniform over the catchment, and $S_{R Z \text { max }}$ is the maximum value of $S_{R Z}$. The amount of water in excess of $S_{R Z \text { max }}$ is redirected to the gravity-drainable unsaturated zone storage. 
The local water balance in the gravity-drainable compartment of unsaturated zone is evaluated for each topographic index class $i$ by solving:

$$
\frac{\Delta S_{U Z_{i}}}{\Delta t}=\frac{\delta S_{R Z}}{\Delta t}-q_{v_{i}}
$$

where $q_{v}$ is the vertical saturated zone recharge by gravity drainage from unsaturated zone $\left[\mathrm{m} \mathrm{s}^{-1}\right]$, which is estimated as:

$q_{v i}=\frac{S_{U Z i}}{t_{d} D_{i}}$

where $S_{U Z}$ is the water storage in the gravitydrainable compartment of the unsaturated zone [m], and $t_{d}$ is a parameter $\left[\mathrm{s} \mathrm{m}^{-1}\right]$ interpreted as the mean residence time in $S_{U Z}$ per unit of saturated zone deficit.

The catchment scale saturated zone recharge $Q_{v}$ $\left[\mathrm{m}^{3} \mathrm{~s}^{-1}\right]$ is equal to the sum of local recharges, which can be expressed as the sum of all topographic index class contributions:

$Q_{v}=\sum_{i} A_{i} q_{v i}$

where $A_{i}$ is the area associated with topographic index class $i\left[\mathrm{~m}^{2}\right]$.

Finally, the catchment scale water balance for the saturated zone is:

$A \frac{\bar{D}_{t}-\bar{D}_{t-\Delta t}}{\Delta t}=\left(Q_{b}-Q_{v}\right)_{t-\Delta t}$

The saturated zone discharge at the catchment scale, $Q_{b}\left[\mathrm{~m}^{3} \mathrm{~s}^{-1}\right]$, can be calculated from the average storage deficit $\bar{D}$ as:

$Q_{b}=Q_{0} e^{-\bar{D} / m}$.

The discharge corresponding to zero average deficit, $Q_{0}\left[\mathrm{~m}^{3} \mathrm{~s}^{-1}\right]$, is determined as:

$Q_{0}=A e^{-\bar{I}}$

where $\bar{I}$ is the mean value of the soil-topographic index over the catchment area $A$.

The local saturated zone deficit can be interpreted as the difference between maximum possible saturated storage $S_{S Z \text { max }}$ and actual storage $S_{S Z \text {, i.e.: }}$

$D_{i}=S_{S Z \max }-S_{S Z i}$
In analogy to Eq. (5), this can be also expressed in terms of hypodermic flow depth:

$$
D_{i}=\Theta\left(h_{S Z \max }-h_{S Z i}\right)
$$

where $h_{S Z \text { max }}$ is equal to the maximum depth of the saturated zone, i.e. in our case the depth of the soil profile (about $75 \mathrm{~cm}$ ).

An important feature of TOPMODEL is the algorithm used for the determination of variable source areas contributing to rapid surface runoff (cf. Figs. 3 and 4). According to TOPMODEL, these areas are formed wherever the local saturated zone storage deficit $D$, calculated from (13), becomes zero (or negative). The saturation excess runoff generated over the variable source areas (Fig. 4) is then added to the combined (subsurface plus surface) discharge $Q(t)$.

Alternatively, surface runoff may be generated via the infiltration excess mechanism. However, this runoff mechanism is rarely if ever observed at Uhliřská and was not considered in the present application of TOPMODEL.

Note the discrepancy between the postulated spatial uniformity of the saturated zone recharge, expressed in (12), and the distributed character of recharge rates calculated from (17). According to the author of TOPMODEL: "The water table is assumed to take up a shape AS IF the recharge rate was uniform across the catchment (even if the recharge is actually heterogeneous). Homogeneity is not the only problem, in fact - a kinematic analysis shows that if there is strong variation in recharge in space or time then it might actually take quite a long time to achieve such a steady state, while differences in soil transmissivity will also have an effect" (Beven, personal communication, 2012).

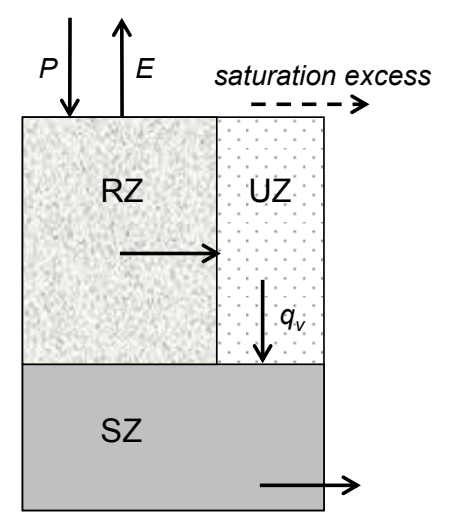

Fig. 3. Schematic of TOPMODEL storages and fluxes $(\mathrm{RZ}=$ root zone storage, $\mathrm{UZ}=$ unsaturated zone storage, $\mathrm{SZ}=$ saturated zone storage). 


\section{Experimental site and measurements}

The above described models were tested using data from the experimental catchment Uhlírská, located in the Jizera Mountains in northeast Czech Republic. The Uhlírská catchment lies in the upper part of the Černá Nisa catchment where basic hydrological and climatological conditions have been monitored since 1982 by the Czech Hydrometeorological Institute. The Uhlírská catchment has an area of $1.78 \mathrm{~km}^{2}$ and an average altitude of $822 \mathrm{~m}$ above sea level. Average annual temperature is $4.7^{\circ} \mathrm{C}$, annual precipitation exceeding $1300 \mathrm{~mm}$. The catchment is generally covered by snow from November to April. The forest at Uhlírská was damaged acid deposition in 80's. The catchment is now covered by young spruce forest with grass undergrowth.

Hydropedological survey has been conducted to determine infiltration and retention characteristics of the soil profile (Šanda, 1999; Zumr et al., 2007). The soil on the weathered porphyric granite bedrock is classified as Dystric Cambisol. The soil type varies from loamy sand to sandy loam and has a very coarse skeleton.

The experimental site is equipped with automatic data collection systems for precipitation, temperature, soil water pressure, soil moisture, subsurface discharge, and other hydrological variables (Šanda, 1999).

Shallow subsurface runoff is measured in a trench situated at the experimental hillslope Tomšovka. The average slope near the trench is $14 \%$. The soil profile is approximately $75 \mathrm{~cm}$ deep followed by weathered bedrock. The trench consists of two sections, each four meters wide (denoted as section $\mathrm{A}$ and section $\mathrm{B}$ ), and both equipped with a tipping bucket flow gauge for measuring subsurface runoff. It is assumed that each section of the trench collects water from an area of about $100 \mathrm{~m}^{2}$ (Císlerová et al., 1997, Šanda et al., 2006; Šanda and Císlerová, 2009).

\section{Model application}

Three different models - S1D, GEOTRANSF and TOPMODEL - were applied to rainfall-runoff data observed at the Uhlírská catchment in vegetation seasons 2000, 2001 and 2002.

The models were used to simulate runoff from a micro-catchment, representing the Tomšovka hillslope site. The size of the micro-catchment was set equal to the estimated contributing area of one of the two sections of the experimental trench. Both hillslope segments (draining to the respective section of the trench) were considered to be $75 \mathrm{~cm}$ deep, $25 \mathrm{~m}$ long and $4 \mathrm{~m}$ wide, with a constant slope of $\tan \beta=0.14$.

The initial soil water storage conditions applied at the beginning of vegetation seasons corresponded to the soil water pressures measured by tensiometers. The soil-atmosphere interactions involved natural rainfall and potential evapotranspiration estimated by Penman-Monteith equation. Hourly averaged rainfall and daily averaged evapotranspiration intensities were utilized as input data for all three models. TOPMODEL as well as GEOTRANSF were run with one-hour time steps. S1D uses adaptive time step associated with the numerical solution.

The S1D model parameters (Tab. 1) were taken from our previous study (Vogel et al., 2010b) conducted for the same experimental site. The model parameters of GEOTRANSF and TOPMODEL were calibrated to match the runoff hydrographs observed in the season 2000. The parameters were optimized by means of the Levenberg-Marquardt algorithm (Marquardt, 1963).

Alternatively, the calibration of GEOTRANSF and TOPMODEL was performed for the subsurface runoff hydrographs generated by the S1D model (for the season 2000), instead of using the observed hydrographs. In this case, the S1D model served as a substitute for the real hillslope. The main advantage of this approach was a significant reduction of complexity and the associated uncertainty in the substitute system, which allowed a more straightforward comparison of the simulated internal fluxes and soil water storages, otherwise unavailable for the real system (such as comparison of $S_{R Z}$ and $S_{U Z}$ storages in TOPMODEL with SM-domain and PFdomain storages in S1D).

In GEOTRANSF, a single parameter was calibrated - the parameter $m$. The calibration yielded a value of $m=0.00803 \mathrm{~m}$ (for the GEOTRANSF vs. $\mathrm{S} 1 \mathrm{D}$ calibration). The minimum specific discharge $q_{0}$ and minimum soil water storage $S_{0}$ were both set equal to zero.

In TOPMODEL, the calibration of the parameters $m$ and $t_{d}$ resulted in $m=0.005 \mathrm{~m}$ and $t_{d}=244 \mathrm{~h} \mathrm{~m}^{-1}$ (for the TOPMODEL vs. S1D calibration). Note that the parameter $m$ plays in TOPMODEL similar role as in GEOTRANSF (see Eqs. (20) and (7)). The root zone storage $S_{R Z \max }$ was set 
equal to $0.165 \mathrm{~m}$. The lateral transmissivity at full saturation was estimated as $T_{0}=0.781 \mathrm{~m}^{2} \mathrm{~h}^{-1}$. The maximum root zone storage $S_{R Z \max }$ was assumed to be equal to the soil water field capacity, i.e. the amount of water stored in initially fully saturated soil after 48 hours of free draining. The value of $S_{R Z \text { max }}$ was determined by integrating the soil water content profile (in SM-domain) at the end of 48hour drainage period simulated by S1D model. The lateral transmissivity at full saturation $T_{0}$ was assumed to be equal to the product of the lateral saturated hydraulic conductivity of the network of effective preferential pathways, estimated as $K_{\text {eff }}=2500 \mathrm{~cm} \mathrm{~d}^{-1}$ and the total depth of the soil profile $(75 \mathrm{~cm})$.

Since the soil-bedrock interface at Tomšovka is semipervious, part of the infiltrating water seeps to deeper horizons and does not contribute to the shallow subsurface discharge. To respect that, vertical flow $q_{v}$ calculated in TOPMODEL was divided into the deep percolation part $q_{d p}$ and the saturated zone recharge part $q_{s}$ using the same partitioning procedure as in GEOTRANSF (Eq. (8)). The catchment scale saturated zone recharge was therefore calculated as:

$Q_{v}=\sum_{i} A_{i} q_{s i}, \quad q_{s i}=\left(1-c_{p}\right) q_{v i}$

The value of partition coefficient $c_{p}=0.36$, determined by S1D model, was also applied in GEOTRANSF and TOPMODEL.

To calculate the local soil-topographic index and the local saturated zone deficit in TOPMODEL, the contributing hillslope area at Tomšovka was divided into five segments (Fig. 4) along the slope length (each $5 \mathrm{~m}$ long).

To compare the models, three performance criteria were used in this study: (i) coefficient of determination $\mathrm{R}^{2}$, (ii) root mean square error RMSE, and (iii) the Nash-Sutcliffe efficiency NSE.

T a b 1 e 1. Soil hydraulic parameters.

\begin{tabular}{|c|c|c|c|c|c|c|c|c|}
\hline Domain & Layer & $\begin{array}{l}\text { Depth } \\
{[\mathrm{cm}]}\end{array}$ & $\begin{array}{c}\theta_{r} \\
{[-]}\end{array}$ & $\begin{array}{c}\theta_{s} \\
{[-]}\end{array}$ & $\begin{array}{c}\alpha \\
{\left[\mathrm{cm}^{-1}\right]}\end{array}$ & $\begin{array}{c}n \\
{[-]}\end{array}$ & $\begin{array}{c}K_{s} \\
{\left[\mathrm{~cm} \mathrm{~d}^{-1}\right]}\end{array}$ & $\begin{array}{c}h_{\mathrm{s}} \\
{[\mathrm{cm}]}\end{array}$ \\
\hline \multirow[t]{4}{*}{ Matrix } & 1 & $0-8$ & 0.20 & 0.55 & 0.050 & 2.00 & 567 & 0.00 \\
\hline & 2 & $8-20$ & 0.20 & 0.54 & 0.050 & 1.50 & 67 & -0.69 \\
\hline & 3 & $20-70$ & 0.20 & 0.49 & 0.020 & 1.20 & 17 & -1.48 \\
\hline & 4 & $70-75$ & 0.20 & 0.41 & 0.020 & 1.20 & 1.3 & -1.88 \\
\hline Preferential & - & $0-75$ & 0.01 & 0.60 & 0.050 & 3.00 & 5000 & 0.00 \\
\hline
\end{tabular}

$\theta_{r}$ and $\theta_{s}$ are the residual and saturated water contents, $h_{\mathrm{s}}$ - the air-entry value, and $\alpha$ and $n$ - empirical parameters (Vogel et al., 2001).

\section{Results and discussion}

Specific subsurface runoff simulated by the S1D model is compared to the observed hillslope discharge in Fig. 5. It is obvious that major hillslope responses occur after abundant rainfall distributed over a longer period of time. The simulated and measured hydrographs are of a similar shape; their rising limbs are very steep. The agreement between the observed and simulated discharges is not perfect, however the model is capable of reproducing the basic character of hillslope responses. Following model performance indices were determined for the three vegetation seasons $(2000,2001,2002): R^{2}$ $=(0.87,0.74,0.90)$, NSE $=(0.86,0.72,0.64)$ and RMSE $=(0.14,0.42,1.7) \mathrm{cm} \mathrm{d}^{-1}$.

Fig. 5 also compares the simulated changes in soil water storage, represented by the amount of water contained in the SM domain, with the observed soil water storage variations. The observed storages were converted from the measured soil water pressures using laboratory determined retention curves. Soil water pressures were measured at five locations each instrumented with three tensiometers. The determination of soil water storage by this approach was rather problematic due to episodic failures of tensiometers and uncertainties related to the schematization of the soil profile and to the representativeness of the available retention curves.

The model performance criteria for GEOTRANSF and TOPMODEL are shown in Tab. 2. Both models succeeded in simulating the hillslope discharges relatively well. In most cases there was a slightly better agreement between the hydrographs predicted by GEOTRANSF and TOPMODEL and those generated by S1D (GEOTRANSF and TOP- 
MODEL vs. S1D) than between the simulated and observed hydrographs (GEOTRANSF and TOPMODEL vs. data). The simulated hydrographs are compared in Fig. 6. The corresponding soil water storages are shown in Fig. 7.

Fig. 7 shows relatively good agreement between the SM-domain storage simulated by S1D and the total soil water storage predicted by GEOTRANSF. This seems to indicate that the soil water storage responses at Tomšovka can be successfully modeled by a zero-dimensional non-linear compartment approach. The TOPMODEL soil water storage is divided into two components: the RZ storage and the UZ storage. This division seems to resemble the S1D dual storage - consisting of SM-domain storage and PF-domain storage. However, as it can be seen in Figs. 7 and 8, the actual functioning of the corresponding storages is quite different. The most notable difference is reflected in the cutoff value of the TOPMODEL RZ storage, caused by the introduction of the field capacity as an upper limit for the RZ storage $\left(S_{R Z \max }\right)$. The comparison of UZ storage in TOPMODEL and PF-domain storage in S1D (Fig. 8a) reveals completely different character of storage responses. This is because the PFdomain storage contains not only gravity-drainable water but also water retained by capillary forces. The TOPMODEL UZ storage is represented by a fictitious reservoir (Eqs. (16) and (17)), which delays the RZ-storage overspills, however in a much less continuous way compared to the vertically distributed S1D PF-domain storage.

In Fig. 8b, saturated zone deficits generated by TOPMODEL (Eq. (13)) are compared with those obtained by applying the S1D model together with Eqs. (4), (6) and (23). Both deficits are evaluated at the hillslope base. The figure shows substantially larger variation range for the TOPMODEL deficit than for the S1D deficit. The scale of the former is controlled by the empirical parameter $m$, but even more importantly, by the selected exponential relationship between transmissivity and storage deficit. More comparable results could probably be ob- tained with a linear transmissivity-deficit relationship, which would also be in a better agreement with our implicit assumption that the effective lateral saturated conductivity is independent of $z$ (e.g. in (6)).

Both S1D and TOPMODEL are capable of predicting the beginning of surface runoff and the amount of locally generated saturation excess water in case that the soil profile becomes fully saturated. Although such an event may have occurred during the simulated period (e.g. in July 2000, September 2001 or August 2002), the available data are insufficient to make a conclusive quantitative comparison between the observed and simulated variables. While S1D predicted no surface runoff over the simulation period, TOPMODEL did predict overland flow due to saturation excess on several occasions. An example of the development of variable saturation area, as predicted by TOPMODEL, is shown in Fig. 4. Another such event occurred on July 17,2001 , as indicated by the sharp decrease of saturated zone deficit to zero in Fig. 8b.

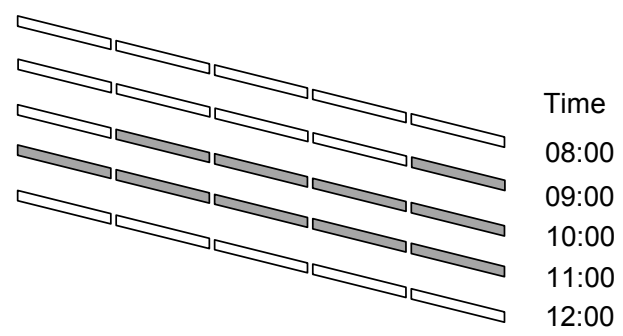

Fig. 4. Variable source area simulated by TOPMODEL during rainfall-runoff episode which occurred on September 11, 2001. The hillslope segment is $25 \mathrm{~m}$ long and consists of 5 elements.

\section{Conclusions}

The studied models were compared in terms of their performance when applied to the simulations of hillslope discharges, observed at the experimental hillslope site. In addition, the adopted methodology allowed us to analyze and compare internal

T a b 1 e 2. Model performance evaluated for GEOTRANSF and TOPMODEL. Model parameters were alternatively calibrated against the observed hillslope discharge hydrographs and the hydrographs generated by S1D model. In both cases, the vegetation season 2000 was used as a calibration period. RMSE is given in $\mathrm{cm} \mathrm{d}^{-1}$.

\begin{tabular}{lllllllllllll}
\hline & \multicolumn{3}{l}{ GEOTRANSF vs. data } & \multicolumn{3}{c}{ TOPMODEL vs. data } & \multicolumn{3}{c}{ GEOTRANSF vs. S1D } & \multicolumn{3}{c}{ TOPMODEL vs. S1D } \\
& $\mathrm{R}^{2}$ & NSE & RMSE & $\mathrm{R}^{2}$ & NSE & RMSE & $\mathrm{R}^{2}$ & NSE & RMSE & $\mathrm{R}^{2}$ & NSE & RMSE \\
\hline 2000 & 0.81 & 0.74 & 0.18 & 0.82 & 0.75 & 0.18 & 0.87 & 0.82 & 0.14 & 0.95 & 0.92 & 0.09 \\
2001 & 0.62 & 0.54 & 0.54 & 0.70 & 0.60 & 0.50 & 0.78 & 0.75 & 0.29 & 0.77 & 0.76 & 0.28 \\
2002 & 0.82 & 0.44 & 2.11 & 0.86 & 0.62 & 2.19 & 0.96 & 0.85 & 0.48 & 0.71 & 065 & 0.74 \\
\hline
\end{tabular}



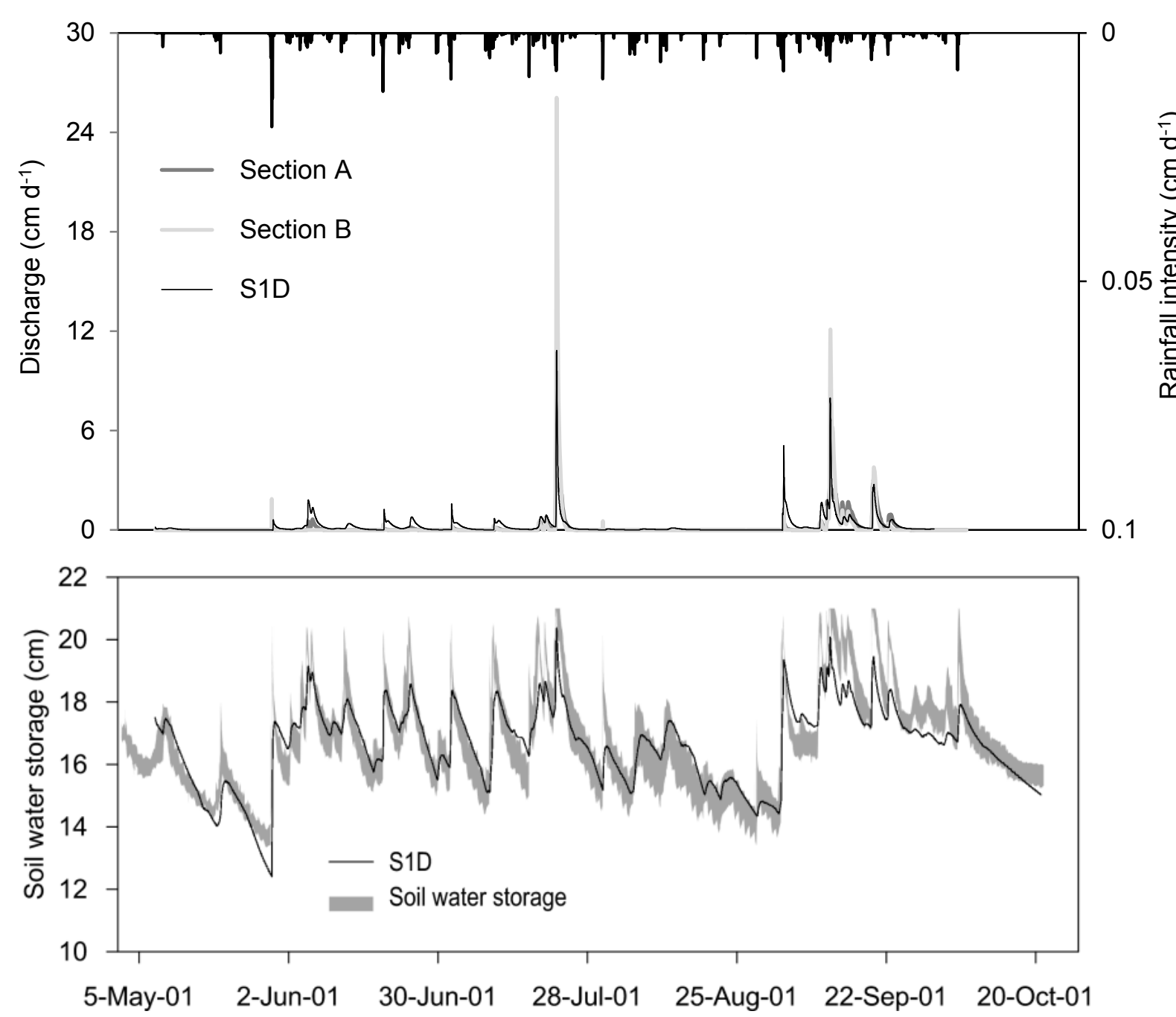

Fig. 5. S1D vs. data in 2001: (a) subsurface hillslope discharge, (b) soil water storage - the shaded area reflects the spatial variability of soil water storage, evaluated from multiple tensiometer measurements.

model fluxes and storages. This is particularly important when internal variables are subject to physical interpretation, such as in TOPMODEL, where the saturation storage deficits are used to determine the occurrence and distribution of variable source areas during rainfalls.

The results confirm that subsurface runoff dominates hydrological responses of the studied hillslope. Considering the uncertainties in the measured data and model parameters, all applied models were able to simulate the hillslope responses to precipitation relatively well. Zero-dimensional and semi-distributed catchment scale models with limited amount of parameters were quite successful in predicting hillslope discharge hydrographs but less so in predicting soil water storage variations.
By choosing a model for hydrological modeling, it is necessary to consider not only the model performance but also the number of model parameters and the procedures necessary to determine their values. In that respect, the GEOTRANSF model, in spite of its simplicity, proved to be a promising tool for modeling hydrological responses of small mountainous catchments with shallow highly permeable soils.

Acknowledgement. The study was supported by the Ministry of Environment of the Czech Republic, Project No. SP/2e7/229/07 and by the Czech Science Foundation, Project No. 205/08/1174. We thank Dr. Martin Šanda (Czech Technical University in Prague) for supervising the field observations at the Tomšovka site. 

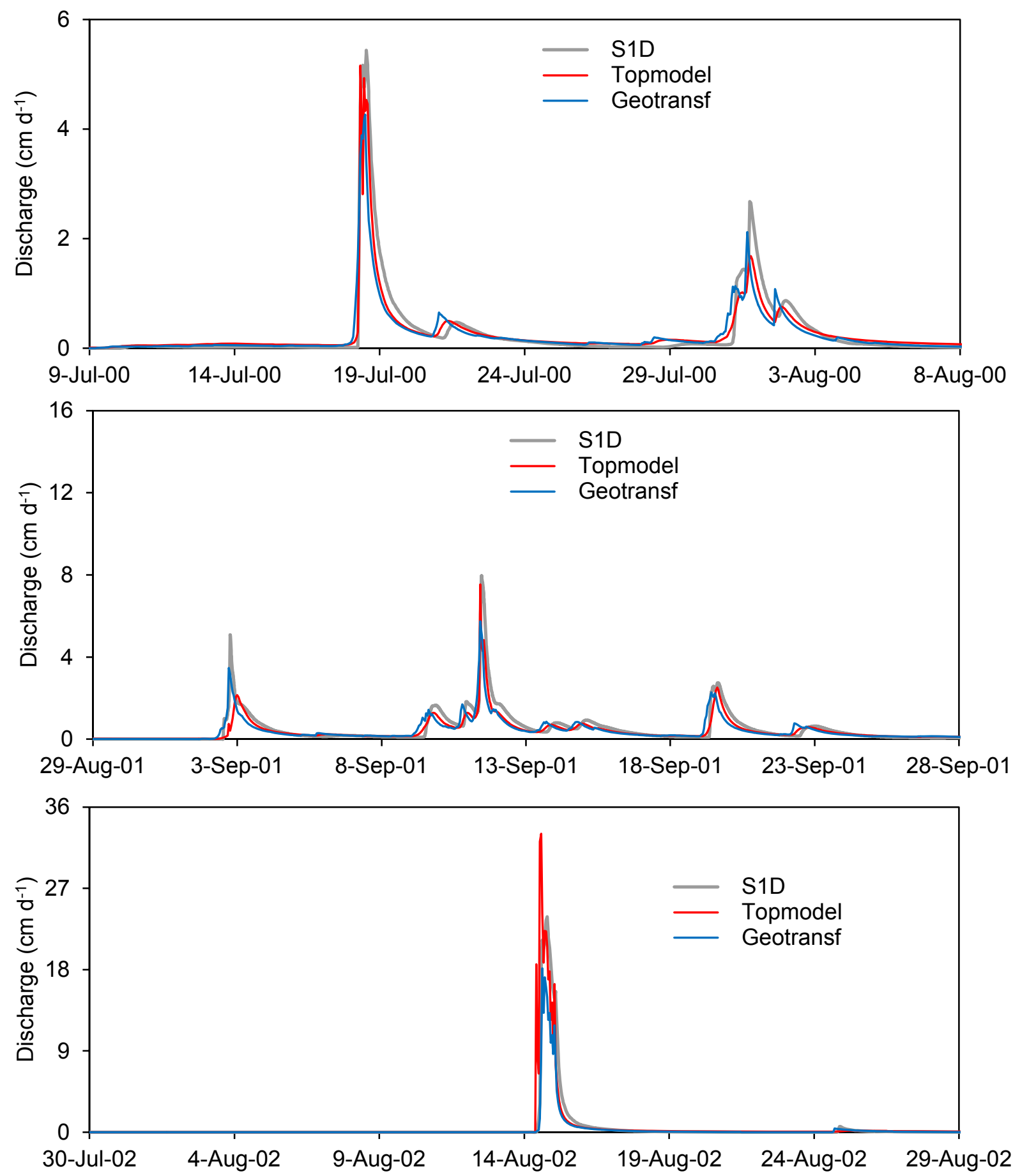

Fig. 6. Subsurface hillslope discharge (30-day details). 

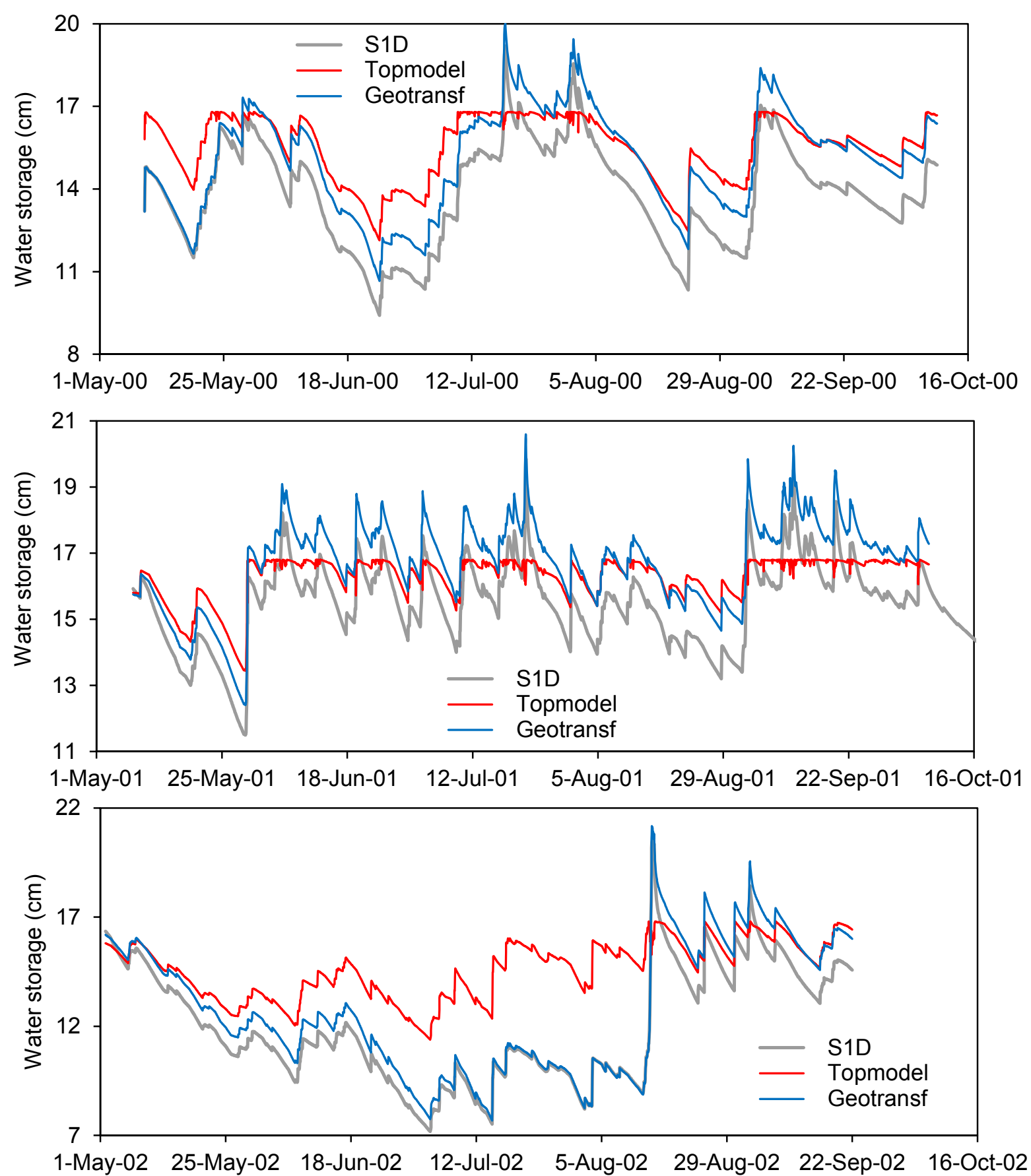

Fig. 7. Simulated SM storage in S1D, total soil water storage in GEOTRANSF, and root zone storage in TOPMODEL. 

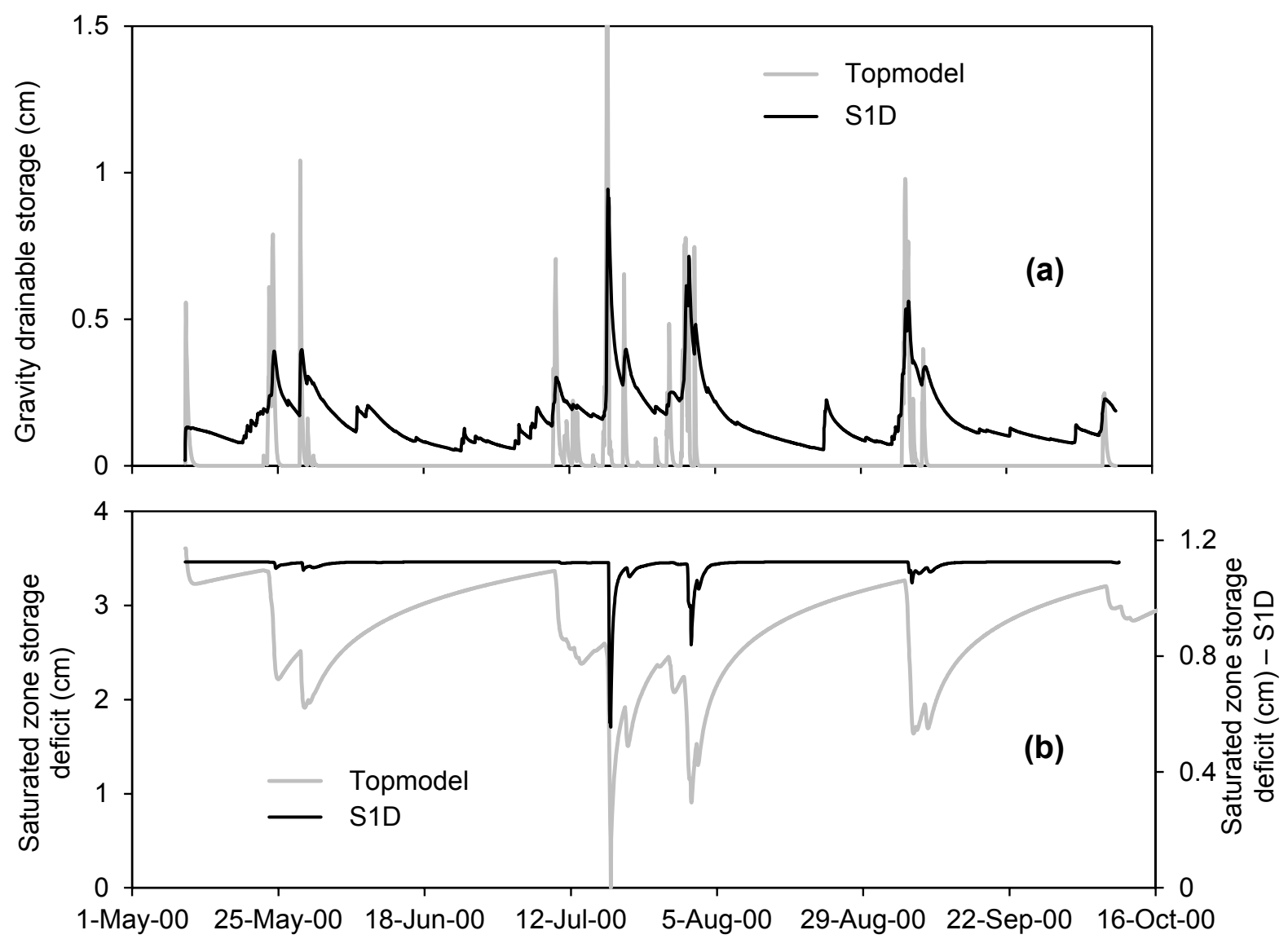

Fig. 8. Simulated gravity-drainable storage in TOPMODEL vs. PF storage in S1D (a) and saturated zone storage deficits determined using TOPMODEL and S1D (b).

\section{List of symbols}

- contributing hillslope area per unit contour length $[\mathrm{m}]$,

- contributing hillslope area $\left[\mathrm{m}^{2}\right]$,

- hillslope width [m],

$C_{f} \quad-$ soil water capacity of preferential flow domain $\left[\mathrm{m}^{-1}\right]$,

$C_{m} \quad-$ soil water capacity of soil matrix domain $\left[\mathrm{m}^{-1}\right]$,

$c_{p} \quad-$ partition coefficient (GEOTRANSF) [-],

$D$ - local saturated zone storage deficit (TOPMODEL) $[\mathrm{m}]$,

$\bar{D} \quad$ - average storage deficit (TOPMODEL) [m],

$E \quad-$ actual evapotranspiration $\left[\mathrm{m} \mathrm{s}^{-1}\right]$,

$h_{f} \quad-$ soil water pressure head in PF domain $[\mathrm{m}]$

$h_{m} \quad-$ soil water pressure head in SM domain [m],

$h_{s z} \quad-$ depth of the saturated hypodermic stream [m],

$h_{s} \quad$ - air-entry value [m],

I - soil-topographic index (TOPMODEL) $\left[\mathrm{s} \mathrm{m}^{-1}\right]$,

$\bar{I} \quad$ - average topographic index (TOPMODEL) $\left[\mathrm{s} \mathrm{m}^{-1}\right]$,

$K_{\text {eff }}-$ effective hydraulic conductivity for hypodermic flow $\left[\mathrm{m} \mathrm{s}^{-1}\right]$,

$K_{f} \quad-$ PF-domain hydraulic conductivity $\left[\mathrm{m} \mathrm{s}^{-1}\right]$,

$K_{m} \quad$ - SM-domain hydraulic conductivity $\left[\mathrm{m} \mathrm{s}^{-1}\right]$
$K_{s} \quad-$ saturated hydraulic conductivity $\left[\mathrm{m} \mathrm{s}^{-1}\right]$,

$m$ - empirical parameters in GEOTRANSF and TOPMODEL [m],

- empirical parameter of van Genuchten retention function [-],

NSE - Nash-Sutcliffe efficiency [-],

$P \quad-$ infiltration intensity $\left[\mathrm{m} \mathrm{s}^{-1}\right]$,

$q_{d p} \quad$ - deep percolation (GEOTRANSF) $\left[\mathrm{m} \mathrm{s}^{-1}\right]$,

$q_{f} \quad-$ vertical soil water flux in PF domain $\left[\mathrm{m} \mathrm{s}^{-1}\right]$,

$q_{h} \quad$ - vertical soil water flux (GEOTRANSF) $\left[\mathrm{m} \mathrm{s}^{-1}\right]$,

$q_{m} \quad-$ vertical soil water flux in SM domain $\left[\mathrm{m} \mathrm{s}^{-1}\right]$,

$q_{s} \quad$ - macropore component of soil water flux (GEOTRANSF) $\left[\mathrm{m} \mathrm{s}^{-1}\right]$,

$q_{v} \quad-$ saturated zone recharge (TOPMODEL) $\left[\mathrm{m} \mathrm{s}^{-1}\right]$,

$q_{0} \quad-$ specific discharge associated with $S_{0}$ (GEOTRANSF) $\left[\mathrm{m} \mathrm{s}^{-1}\right]$,

$Q \quad-$ hillslope discharge $\left[\mathrm{m}^{3} \mathrm{~s}^{-1}\right]$,

$Q_{b} \quad$ - saturated zone discharge (TOPMODEL) $\left[\mathrm{m}^{3} \mathrm{~s}^{-1}\right]$,

$Q_{v} \quad$ - saturated zone recharge (TOPMODEL) $\left[\mathrm{m}^{3} \mathrm{~s}^{-1}\right]$,

$Q_{0} \quad$ - discharge corresponding to zero average deficit (TOPMODEL) $\left[\mathrm{m}^{3} \mathrm{~s}^{-1}\right]$,

$R \quad-$ saturated zone recharge $\left[\mathrm{m} \mathrm{s}^{-1}\right]$,

$\mathrm{R}^{2}-$ coefficient of determination $[-]$,

RMSE - Root Mean Square Error $\left[\mathrm{m} \mathrm{s}^{-1}\right]$, 
$S \quad-$ soil water storage [m],

$S_{f} \quad-$ root water uptake in PF-domain $\left[\mathrm{s}^{-1}\right]$,

$S_{m} \quad-$ root water uptake in SM-domain $\left[\mathrm{s}^{-1}\right]$,

$S_{S Z} \quad$ - saturated zone storage (TOPMODEL) [m],

$S_{R Z}$ - soil water storage in the root zone (TOPMODEL) $[\mathrm{m}]$,

$S_{U Z} \quad-$ soil water storage in unsaturated zone (TOPMODEL) $[\mathrm{m}]$,

$S_{0} \quad-$ minimum threshold value of soil water storage (GEOTRANSF) [m],

- time [s],

- empirical parameter (TOPMODEL) $\left[\mathrm{s} \mathrm{m}^{-1}\right]$,

- lateral transmissivity at full soil saturation (TOPMODEL) $\left[\mathrm{m}^{2} \mathrm{~s}^{-1}\right]$,

$w_{f} \quad-$ volume fraction of PF-domain $[-]$,

$w_{m} \quad-$ volume fraction of SM-domain $[-]$,

$\alpha$ - empirical parameter of van Genuchten retention function $\left[\mathrm{m}^{-1}\right]$,

$\alpha_{w} \quad$ - inter-domain soil water transfer coefficient $\left[\mathrm{s}^{-1} \mathrm{~m}^{-1}\right]$,

$\beta \quad-$ hillslope angle $[-]$,

$\theta_{s} \quad$ - saturated water content $\left[\mathrm{m}^{3} \mathrm{~m}^{-3}\right]$,

$\theta_{r} \quad-$ residual water content $\left[\mathrm{m}^{3} \mathrm{~m}^{-3}\right]$,

$\Gamma_{w} \quad-$ first order soil water transfer term $\left[\mathrm{s}^{-1}\right]$,

$\Theta \quad-$ effective porosity for hypodermic flow $[-]$.

\section{REFERENCES}

AMBROISE B., BEVEN K. J., FREER J., 1996: Toward a generalisation of the TOPMODEL concepts: Topographic indices of hydrological similarity. Water Resour. Res., 32, p. 2135-2145.

BEVEN K. J., 1986: Hillslope runoff processes and flood frequency characteristics, in Hillslope Processes, edited by A.D. Abrahams, pp. 187-202, Allen and Unwin, Winchester, Mass.

BEVEN K. J., 2001: Rainfall-Runoff Modelling. The Primer, John Wiley, New York.

BLAŽKOVÁ Š., BEVEN K. J., 1997: Flood frequency prediction for data limited catchments in the Czech Republic using a stochastic rainfall model and TOPMODEL. J. Hydrol., 195, 256-278.

BLAŽKOVÁ Š., BEVEN K. J., TACHECÍ P., KULASOVÁ A., 2002a: Testing the distributed water table predictions of TOPMODEL (allowing for uncertainty in model calibration): The death of TOPMODEL? Water Resour. Res., 38, Article No. 1257.

BLAŽKOVÁ Š., BEVEN K. J., KULASOVÁ A., 2002b: On constraining TOPMODEL hydrograph simulations using partial saturated area information. Hydrol. Process., 16, 441-458.

CÍSLEROVÁ M., ŠANDA M., BLAŽKOVÁ Š., MAZÁČ O., GRÜNWALD A., ZEITHAMMEROVÁ J., TACHECÍ P., 1997: Ecological aspects of the water resources protection: Transport processes in a watershed affected by abrupt changes of runoff conditions (Jizera Mountains). (In Czech.) Res. Rep. VaV/510/3/96-DÚ 01. Ministry of Environ., Czech Republic, Prague.

CORDANO E., RIGON R., 2008: A perturbative view on the subsurface water pressure response at hillslope scale, Water Resour. Res., 44, W05407.
DOHNAL M., DUŠEK J., VOGEL T., 2006: The impact of the retention curve hysteresis on prediction of soil water dynamics. J. Hydrol. Hydromech., 54, 258-268.

FAN Y., BRAS R., 1998: Analytical solutions to hillslope subsurface storm flow and saturation overland flow. Water Resour. Res., 34, 921-927.

GERKE H. H., VAN GENUCHTEN M. Th., 1993: A dualporosity model for simulating the preferential movement of water and solutes in structured porous media. Water Resour. Res., 29, 305-319.

HILBERTS A. G. J., VAN LOON E. E., TROCH P. A., PANICONI C., 2004: The hillslope-storage Boussinesq model for non-constant bedrock slope. J. Hydrol., 291, $160-173$.

HILBERTS A. G. J., TROCH P. A., PANICONI C., BOL J., 2007: Low-dimensional modeling of hillslope subsurface flow: Relationship between rainfall, recharge, and unsaturated storage dynamics. Water Resour. Res., 43, W03445.

KIRKBY M. J., 1975: Hydrograph modelling strategies, in Process in Physical and Human Geography, edited by R. Peel, M. Chisholm, and P. Haggett, p. 69-90, Heinemann, London.

LICHNER L., ELDRIDGE D. J., SCHACHT K., ZHUKOVA N., HOLKO L., SIR M., PECHO J., 2011: Grass Cover Influences Hydrophysical Parameters and Heterogeneity of Water Flow in a Sandy Soil. Pedosphere, 21, 719-729.

MAJONE B., BERTAGNOLI A., BELLIN A., RINALDO A., 2005: GEOTRANSF: a continuous non-linear hydrological model. Eos Trans. AGU, 86 (52), Fall Meet. Suppl., Abstract $\mathrm{H} 23 \mathrm{C}-1441$.

MAJONE B., BERTAGNOLI A., BELLIN A., 2010: A nonlinear runoff generation model in a small Alpine catchment. J. Hydrol., 385, 300-312.

MARQUARDT D., 1963: An Algorithm for Least-Squares Estimation of Nonlinear Parameters, SIAM J. on Applied Mathematics, 11, 431-441.

PANICONI C., TROCH P. A., VAN LOON E. E., HILBERTS A. G. J., 2003: Hillslope-storage Boussinesq model for subsurface flow and variable source areas along complex hillslopes: 2. Intercomparison with a three-dimensional Richards equation model. Water Resour. Res., 39, Article No. 1317.

TROCH P. A., VAN LOON E. E., HILBERTS A. G. J., 2002: Analytical solutions to a hillslope-storage kinematic wave equation for subsurface flow. Adv. Water Resour., 25, 637-649.

TROCH P. A., PANICONI C., VAN LOON E. E., 2003: Hillslope-storage Boussinesq model for subsurface flow and variable source areas along complex hillslopes: 1. Formulation and characteristic response. Water Resour. Res., 39, Article No. 1316.

ŠANDA M., 1999, Tvorba podpovrchového odtoku na svahu. [Doctoral thesis.], CTU in Prague, Prague.

ŠANDA M., HRNČÍŘ M., NOVÁK L., CÍSLEROVÁ M., 2006: Impact of the soil profile on the rainfall-runoff process. [In Czech.] J. Hydrol. Hydromech., 54, 183-191.

ŠANDA M., CÍSLEROVÁ M., 2009: Transforming hydrographs in the hillslope subsurface. J. Hydrol. Hydromech., $57,4,264-275$.

VOGEL T., VAN GENUCHTEN M.TH., CÍSLEROVÁ M., 2001: Effects of the Shape of the Soil Hydraulic Functions near Saturation on Variably-Saturated Flow Predictions. Adv. Water Resour., 24, 133-144. 
VOGEL T., 2005a: Catchment Runoff Generation - Flow Separation Model. In: Hydrologie malého povodí 2005. Prague: The Institute of Hydrodynamics of the ASCR, 351-357.

VOGEL T., 2005b: Simplified dual continuum approach to modeling subsurface runoff from a hillslope segment. Abstr. no. EGU05-A-07684, In: Geophysical Research Abstracts Volume 7, Katlenburg-Lindau, Copernicus GmbH.

VOGEL T., BŘEZINA J., DOHNAL M., DUŠEK J., 2010a: Physical and numerical coupling in dual-continuum modeling of preferential flow. Vadose Zone J., 9, 260-267.
VOGEL T., ŠANDA M., DUŠEK J., DOHNAL M., VOTRUBOVÁ J., 2010b: Using Oxygen-18 to Study the Role of Preferential Flow in the Formation of Hillslope Runoff. Vadose Zone J., 9, 252-259.

ZUMR D., SNĚHOTA M., CÍSLEROVÁ M., 2007: Application of Fluorescent Tracers on Observation of Preferential Flow. In: American Geophysical Union Fall Meeting 2007 Abstracts, San Francisco, CA.

Received 14 April 2011 Accepted 13 March 2012 